\title{
Modeling of Financial Behavior of the Population
}

\section{Ludmila Ivanovna Nivorozhkina}

Rostov State University of Economics, Rostov-on-Don, Russia

Tatiana Viktorovna Toropova

Rostov State University of Economics, Rostov-on-Don, Russia

Email: ttoropova@mail.ru

\section{Elina Ulukmanovna Yarashanova}

The Chechen State University, Grozny, Russia

Ruslan Vahaevich Batashev

The Chechen State University, Grozny, Russia

Doi:10.5901/mjss.2015.v6n3s3p337

\section{Abstract}

The article presents the results of analysis of the saving and credit activities of different socioeconomic groups of the population of Russia, according to the representative survey of the population "Generations and Gender Survey." Modern econometric techniques were used to analyze different financial strategies of households. "Portraits" of households were drawn to show different strategies of the saving and credit behavior. Conclusions were made about the degree of influence of economic and socio-demographic characteristics of households on their financial behavior.

Keywords: households, saving behavior of households, credit behavior of households, econometric models

\section{Introduction}

The financial behavior of the population depends on many objective and subjective factors: cash income, inflation, currency exchange rates, interest rates on bank products, expectations of the population regarding the prospects of development of the country, etc.

Development of consumer lending is the factor that complicates the financial behavior of the population. Thanks to the development of many types of available consumer lending, the consumer and saving actions have ceased to be alternative in the modern economy (Ibragimov, 2009). In the circumstances of the growing diversity of schemes for mobilizing the funds of households, the simultaneous increase in both consumption and saving has become possible.

In recent years, the proportion of borrowers on consumer and mortgage loans in Russia has been growing rapidly, so has the number and amounts of arrears of current payments for credits. For example, according to the Bank of Russia, as of January 1, 2014, individuals had received credits amounting to 8.778 trillion rubles, which is by 1.552 trillion rubles, or $21.5 \%$, more than a year ago. The total debt of individuals as of December 1, 2014 is 9.730 trillion rubles, which is about 67,713 rubles for each inhabitant of Russia. With account of the nominal wage, to repay the accumulated debt in a single payment, every economically active inhabitant of the Russian Federation should give away an average of 4.3 monthly salaries.

In parallel with the growth of the credit market, the share of outstanding credits grows. As of December 1, 2014, the total amount of arrears amounted to 670.927 billion rubles, or $8.6 \%$ of the total indebtedness of individuals.

The savings activity of the Russian population also shows a positive trend. For example, in 2013, the total savings of the population increased by $14.6 \%$. However, the growth of aggregate savings of the population goes behind the growth of the credit market: in 2013, the increase in the volume of credits was 16.2 times higher than the growth of savings.

The presented statistical macro data do not indicate, which groups are most active with respect to the saving and credit behavior. And this article aims to answer this question. 


\section{Literature Review}

Studies of the financial behavior of the population regularly appear on the pages of economic and financial publications (Burdyak, 2014; Galishnikova, 2012; Yarasheva \& Burdastova, 2012). All of them, as a rule, rely on the theory of absolute income (Keynes, 1999), the theory of relative income (Duesenberry, 1974), the life-cycle theory (Modigliani \& Neisser, 1953), and the theory of permanent income (Friedman, 1957).

An alternative approach, based on the theory developed by J. Katona (Katona, 1951) proposes to consider the impact of objective economic conditions on the behavior of people through the subjective perception of them. For example, in Katona's model, current savings are determined not only by the ability of people to save part of their income for the future at the peak of the economic situation, but also the desire to do it. Katona suggested that the actual saving behavior of households does not always follow the economic model of consumption smoothing: while the income decrease is considered as temporary only, consumption is actually smoothed by reducing savings, or even spending a part of them. But if the worsening is accompanied by expectations of further fall in income, people prefer to reduce consumption and increase savings.

As applied to Russian households, the study of the financial behavior within the framework of a certain approach is contained in the works by L.Ovcharova (Ovcharova, 2008, 2014), D. Ibrahimova (Ibragimova, 2009, 2013), O. Kuzina (Kuzina, 1998, 2009), D. Strebkov (Strebkov, 2007), L. Nivorozhkina (Nivorozhkina, 2013, 2014).

But despite the constant scientific interest, the topic contains multiple gaps. In line with the extensive study of economic processes, we conduct an in-depth analysis of the financial behavior of the population based on the microstatistics data.

\section{Methodology}

The available official statistics data allow identifying the general trends in the financial behavior of the population. However, they are not informative for identifying the specifics of such behavior. The answer to the question of who the "saver" and the "borrower" are can be given only based on the microdata of representative surveys of the population.

One of sources of such microdata is GGS (Generations and Gender Survey) covering the period between 2004 and 2011. We have three rounds of the panel survey: the first wave - in 2004, the second wave - in 2007, and the third wave -2011.

To explain the financial behavior of the population and build a typology of households showing different strategies of the saving and credit behavior, the article offers several models:

1) Logistic binary regression, in which the dependent is a binary variable, the values of which are formed based on the respondents' answers to the question: "Do you or your household currently have savings? ".

2) A multinomial logistic model, in which the dependent variable was the data on households, which since 2000 had not taken credits, taken one credit, or taken two or more credits.

3) Binary logistic models evaluating the determinants of the credit type choice.

4) A set of bivariate probit models (Green, 2000) evaluating the relationship between the having of a credit and the existence of arrears of mandatory payments (rent, mortgage payments, payment of utility bills, etc.), as well as the relationship of credit intentions and experience in credits.

\section{Results}

\subsection{Determinants of households' savings}

Estimates of the parameters of a binary logit model explaining the having of savings by households are presented in Table 1. The models were specified separately for each of the last two rounds (the first round did not contain questions about having savings) of the survey, as well as jointly for two waves with account of the panel structure of the data (Toropova, Tregubova, Yaraskhanova 2013).

The independent variables included: income; variables describing assets of the household: the number of rooms in the dwelling, the form of tenure, ownership of a summer cottage, a garden house, or a car; a set of personal characteristics of the household: the household size, the type of settlement, the region type, the household type with regard to the labor market, the demographic household type, and education.

20 percent income groups were used as the income variable, as in this case, no deflation of income due to inflation between the studied time intervals is required. The variable "the number of rooms in a dwelling" takes values between 
one and ten. $40 \%$ of the "saving" households live in single-bedroom dwellings and about $35 \%$ of them - in two-bedroom dwellings. The variable "the form of tenure" has two grades: owned and not owned dwelling. According to GGS, more than $80 \%$ of households that have savings do not have their own dwelling. The household size is determined by the number of members living in it. We used the socioeconomic typology of regions proposed by N.V. Zubarevich (Zubarevich, 2005) as the variable "the type of region".

Table 1. Estimates of the parameters of the binary logistic regression (the dependent variable - the having of savings by a household)

\begin{tabular}{|c|c|c|c|c|c|c|}
\hline \multirow{2}{*}{ Variables } & \multicolumn{2}{|c|}{ Model 1 (spatial data for 2007) } & \multicolumn{2}{|c|}{ Model 2 (spatial data for 2011) } & \multicolumn{2}{|c|}{ Model 3 (panel data) } \\
\hline & Coefficient $\beta$ & $\operatorname{Exp}(\beta)$ & Coefficient $\beta$ & $\operatorname{Exp}(\beta)$ & Coefficient $\beta$ & $\operatorname{Exp}(\beta)$ \\
\hline \multicolumn{7}{|c|}{ Quintiles by income (first) } \\
\hline second & $0.334^{\star \star \star}$ & 1.396 & $0.452^{\star \star \star}$ & 1.571 & $0.473^{\star \star \star}$ & 1.606 \\
\hline third & $0.663^{\star \star \star}$ & 1.940 & $0.663^{\star \star \star}$ & 1.941 & $0.821^{\star * \star}$ & 2.274 \\
\hline fourth & $0.924^{\star \star \star}$ & 2.519 & $1.077^{\star \star \star}$ & 2.936 & $1.257^{\star \star \star}$ & 3.518 \\
\hline fifth & $1.222^{\star \star \star}$ & 3.393 & $1.408^{\star \star \star}$ & 4.087 & 1.660 *** & 5.264 \\
\hline \multicolumn{7}{|c|}{ Is there a car (no) } \\
\hline Yes & $0.309^{\star \star \star}$ & 1.362 & $0.253^{\star \star \star}$ & 1.288 & $0.368^{\star \star \star}$ & 1.445 \\
\hline \multicolumn{7}{|c|}{ Is there a garden house (no) } \\
\hline Yes & $0.553^{\star \star \star}$ & 1.739 & $0.341^{\star \star \star}$ & 1.406 & $0.505^{\star \star \star}$ & 1.656 \\
\hline The number of rooms in the dwelling & $0.104^{\star \star \star}$ & 1.110 & 0.033 & 1.033 & $0.082^{\star \star \star}$ & 1.086 \\
\hline \multicolumn{7}{|c|}{ Form of ownership of the dwelling (not owned dwelling) } \\
\hline owned & $-0.318^{\star \star \star}$ & 0.728 & $0.267^{\star \star \star}$ & 1.306 & $-0.368^{\star \star \star}$ & 0.691 \\
\hline Household size & -0.013 & 0.987 & 0.017 & 1.017 & 0.015 & 1.015 \\
\hline \multicolumn{7}{|c|}{ The demographic type of household (single households) } \\
\hline single-parent & -0.250 & 0.779 & -0.155 & 0.857 & -0.246 & 0.781 \\
\hline spouses without children & $0.325^{\star \star \star}$ & 1.384 & 0.008 & 1.008 & $0.171^{*}$ & 1.186 \\
\hline spouses with children & -0.042 & 0.958 & -0.170 & 0.843 & -0.163 & 0.849 \\
\hline complex with children & 0.014 & 1.014 & $-0.108^{*}$ & 0.898 & $-0.287^{*}$ & 0.750 \\
\hline complex without children & -0.105 & 0.900 & -0.306 & 0.737 & -0.081 & 0.921 \\
\hline \multicolumn{7}{|c|}{ Type of settlement (regional center) } \\
\hline Village & $-0.244^{\star \star \star}$ & 0.783 & $-0.267^{\star \star \star}$ & 0.765 & $-0.248^{\star \star \star}$ & 0.780 \\
\hline City & $-0.204^{\star \star}$ & 0.815 & $-0.177^{\star \star}$ & 0.838 & $-0.339 * * *$ & 0.712 \\
\hline Urban-type settlement & 0.097 & 1.102 & 0.089 & 1.093 & 0.135 & 1.145 \\
\hline \multicolumn{7}{|c|}{ Education (higher and postgraduate) } \\
\hline $\begin{array}{c}\text { Incomplete secondary (9 years or } \\
\text { less) }\end{array}$ & -0.042 & ,959 & 0.099 & 1.104 & 0.102 & 1.108 \\
\hline Secondary (9-11 years of study) & $-0.476^{\star \star \star}$ & 0.622 & $-0.371^{\star \star \star}$ & 0.690 & $-0.395^{\star \star \star}$ & 0.673 \\
\hline Elementary vocational education & $-0.393^{\star * *}$ & 0.675 & $-0.231^{\star * *}$ & 0.794 & $-0.462^{\star \star \star}$ & 0.629 \\
\hline $\begin{array}{c}\text { Secondary vocational education and } \\
\text { undergraduate education }\end{array}$ & $-0.219 * \star \star$ & 0.803 & $-0.182^{\star \star *}$ & 0.834 & $-0.270^{\star * *}$ & 0.763 \\
\hline \multicolumn{7}{|c|}{ The type of household by the relation to the labor market (all members of the household are inactive) } \\
\hline $\begin{array}{l}\text { all members of the household are } \\
\text { active }\end{array}$ & $0.376^{*}$ & 1.456 & $0.522^{\star \star}$ & 1.685 & $0.514^{\star \star *}$ & 1.673 \\
\hline retirees + inactive & $0.709^{\star \star \star}$ & 2.032 & $1.058^{\star \star \star}$ & 2.880 & $1.021^{\star \star \star}$ & 2.777 \\
\hline $\begin{array}{l}\text { at least one member of the } \\
\text { household is active }\end{array}$ & 0.301 & 1.351 & $0.614^{\star *}$ & 1.848 & $0.519 * * *$ & 1.681 \\
\hline \multicolumn{7}{|c|}{ Region type ("outsiders") } \\
\hline "middle" & $0.654^{\star \star \star}$ & 1.923 & 0.077 & 1.080 & $0.495^{\star \star \star}$ & 1.640 \\
\hline $\begin{array}{l}\text { "relatively developed or ahead by } \\
\text { income" }\end{array}$ & $0.510 * \star *$ & 1.666 & 0.152 & 1.165 & $0.455^{\star \star *}$ & 1.576 \\
\hline "leaders" & $0.407^{*}$ & 1.503 & 0.119 & 1.127 & $0.381^{*}$ & 1.463 \\
\hline \multicolumn{7}{|c|}{ Time factor (2007) } \\
\hline 2011 & - & - & - & - & $0.132^{\star \star \star}$ & 1.141 \\
\hline Constant & $-2.144^{\star \star *}$ & 0.117 & $-2.008^{\star \star \star}$ & 0.134 & $-2.498^{\star \star \star}$ & 0.082 \\
\hline$-2 \mathrm{LL}$ & \multicolumn{2}{|l|}{6842.243} & \multicolumn{2}{|l|}{6965.733} & \multicolumn{2}{|c|}{6831.7396} \\
\hline chi-square & \multicolumn{2}{|l|}{$562.931^{\text {*** }}$} & \multicolumn{2}{|l|}{$626.531^{\star \star \star}$} & \multicolumn{2}{|c|}{$760.73^{\star \star \star}$} \\
\hline Sample size & \multicolumn{2}{|l|}{5641} & \multicolumn{2}{|l|}{5641} & \multicolumn{2}{|l|}{11282} \\
\hline
\end{tabular}

${ }^{* \star *},{ }^{* *},{ }^{*}$ is significant at the level of 1,5 , and $10 \%$, respectively. The reference categories are shown in parentheses. 
Moving households to a higher income group increases the probability of having savings. Thus, compared with the households included in the lowest income group, the chances of having savings in households belonging to the second income group will be 1.60 times higher, the third group - 2.27 times higher, the fourth group - 3.51 times higher, and the fifth income group - 5.26 times higher.

Ownership of liquid assets increases the chances of households to have savings. For example, if a household has a car, then the chances of having savings increase by $45 \%$; if it has a summer cottage or a garden house, the chances are higher by $66 \%$. The values of the corresponding coefficients in models 1 and 2 also show higher chances of having savings in households, which have these amenities.

The increasing number of rooms in a dwelling increases the probability to have savings by $8.6 \%$. For 2011 , this factor is not statistically significant.

Owned dwelling, according to the coefficient with the corresponding variable in model 3, reduces the likelihood of having savings by $30.9 \%$. At the same time in 2007 , owning dwelling reduced the probability of having savings by $27.2 \%$, while in 2011 , on the contrary, it increased the chances of having savings by $30.6 \%$. Perhaps this fact is related to the fact that in the pre-crisis 2007, households without dwelling accumulated savings to purchase it; and therefore, as compared to those having own dwelling, more often reported about available savings. During the recessionary 2008 and the post-crisis period, the accumulated savings were spent for purchasing dwelling; therefore, in 2011, households without dwelling no longer reported that they had savings.

The household size has no significant effect on the probability of having savings.

In urban and rural areas, compared with regional centers, the chances of households to have savings were lower (by $29 \%$ and $22 \%$, respectively).

Compared with households in the outsider regions, the chances of households to have savings are higher if they belong to the "medium" regions (1.64 times), the "relatively developed or ahead by income" regions (1.58 times), and the leading regions (1.46 times).

Taking as the reference type of households by the relation to the labor market the category "all members of the household are inactive", the presence of at least one active member increases the likelihood of having savings by $68.1 \%$. If all household members are active, the chances of having savings are higher by $67.3 \%$. An interesting result was obtained for households, which have non-working retirees. This category has the highest odds of having savings compared with the reference: for them, the probability of having savings is 2.777 times higher. These results for households containing non-working retirees, can be explained, first, by the quite substantial growth of pensions in 20082010 with simultaneous reduction of real wages; secondly, by the fact that retirees had savings accumulated in previous periods.

With regard to the demographic composition, compared with the reference category "single households", two types influenced statistically significantly on the dependent variable: "spouses without children" and "complex with children." The chances of spouses without children to have savings are by 19\% higher compared with the reference. "Complex with children" households demonstrated statistically significant reduction in the probability to have savings by $25 \%$. It should be noted that when estimating regressions separately for each wave, the household type "spouses without children" influenced significantly in 2007, and the type "complex with children" - in 2011.

Below higher education results in lowering the chances to have savings. For example, the chances of an individual with secondary vocational or undergraduate education to have savings are lower by $24 \%$; and of an individual with elementary vocational education - lower by $37 \%$.

Accounting for the panel data structure revealed a statistically significant influence of the time factor on the saving behavior of households: the chances of households to have savings were higher in 2011 compared to 2007 by an average of 14\%. These positive developments evidence stabilization of the financial position of households by 2011 and their fairly rapid recovery from the crisis.

\subsection{Intensity of credit behavior}

The experience of households' participation in the practice of borrowing, according to GGS, can be estimated based on the responses to the following question: "Have you or members of your household had to buy anything on credit for the purchase of any durable goods, apartments, villas, payment of medical treatment, education, and the like over the past three years?" In the questionnaires of 2011, the question was formulated as follows: "Have you or members of your household had to buy anything on credit or borrow for the purchase of any durable goods, apartments, villas, payment of medical treatment, education, and the like starting from 2000?" Thus, the first question covers the interval between 2004 and 2007, and the second - between 2000 and 2011. 
Estimates of the multinomial logit model explaining the different intensity of credit behavior are shown in Table 2.

The following household characteristics were used as the independent variables: the number of the quintile, which contains the per capita income of households; the demographic type of the household; the number of people employed in the household; the type of employment; the education level of the respondent; the type of community and region according to the classification developed by N.V. Zubarevich.

Table 2. The multinomial model of the number of credits taken

(Reference - "no credits")

\begin{tabular}{|c|c|c|c|c|}
\hline \multirow[b]{2}{*}{ Variables } & \multicolumn{2}{|c|}{ One credit } & \multicolumn{2}{|c|}{ Two or more credits } \\
\hline & \begin{tabular}{c|c|} 
- \\
coefficient
\end{tabular} & $\begin{array}{l}\text { The chances } \\
\text { ratio }\end{array}$ & \begin{tabular}{c|c|}
$\beta-$ \\
coefficient
\end{tabular} & $\begin{array}{l}\text { The chances } \\
\text { ratio }\end{array}$ \\
\hline Free term & -2.970 & - & -1.945 & - \\
\hline \multicolumn{5}{|c|}{ Demographic type of the household (single) } \\
\hline Single-parent families & $0.658^{* *}$ & 1.930 & $0.691^{* *}$ & 1.996 \\
\hline Spouses without children & $0.305^{* *}$ & 1.357 & $0.557^{* k}$ & 1.745 \\
\hline Spouses with children & $0.866^{\star \star *}$ & 2.378 & $1.379^{* * *}$ & 3.969 \\
\hline Complex without children & $0.731^{\text {*** }}$ & 2.077 & $1.164^{* \star *}$ & 3.202 \\
\hline Complex with children & $0.452^{\text {*** }}$ & 1.571 & $0.825^{* \star *}$ & 2.283 \\
\hline \multicolumn{5}{|c|}{20 percent income groups (first) } \\
\hline Second & $0.325^{\text {k*k }}$ & 1.384 & 0.173 & 1.189 \\
\hline Third & $0.192^{*}$ & 1.212 & $0.489^{* k *}$ & 1.630 \\
\hline Fourth & $0.219^{*}$ & 1.245 & $0.469^{* *}$ & 1.599 \\
\hline Fifth & $0.329^{* *}$ & 1.390 & $0.342^{* *}$ & 1.408 \\
\hline \multicolumn{5}{|c|}{ Region type (outsiders) } \\
\hline Middle & $0.466^{* *}$ & 1.594 & $-0.789^{*+1 *}$ & 0.454 \\
\hline Relatively developed or ahead by income & $0.365^{*}$ & 1.440 & $-0.631^{* *}$ & 0.532 \\
\hline Leaders & 0.022 & 1.022 & $-1.268^{\text {*tok }}$ & 0.281 \\
\hline \multicolumn{5}{|c|}{ Type of settlement (regional center) } \\
\hline City & 0.081 & 1.085 & $0.243^{* *}$ & 1.275 \\
\hline Urban-type settlement & $-0.345^{* \star}$ & 0.708 & $-1.143^{* k t}$ & 0.319 \\
\hline Rural-type settlement & -0.086 & 0.918 & 0.003 & 1.004 \\
\hline \multicolumn{5}{|c|}{ Education of the responder (up to 9 years of study) } \\
\hline $9-11$ years of study & $0.736^{\text {*** }}$ & 1.879 & $0.469^{* *}$ & 1.598 \\
\hline Elementary vocational education & $0.891^{\text {** }}$ & 2.087 & $0.521^{*}$ & 1.684 \\
\hline Secondary vocational education and undergraduate education & $0.631^{\text {*k* }}$ & 2.438 & 0.434 & 1.544 \\
\hline Higher and postgraduate education & $0.545^{* *}$ & 1.725 & $0.639^{* *}$ & 1.895 \\
\hline \multicolumn{5}{|c|}{ Employment type of the household (all members of the household are "active", i.e. are self-reliant financially) } \\
\hline $\begin{array}{c}\text { retirees + "inactive" (i.e. financially dependent on the other members of } \\
\text { the household) }\end{array}$ & -0.566 & 0.568 & $-2.181^{* *}$ & 0.113 \\
\hline at least one member of the household is "active" & -0.139 & 0.869 & $-0.241^{* *}$ & 0.786 \\
\hline $\begin{array}{l}\text { all members of the household are "inactive" (this includes the } \\
\text { unemployed, students, the disabled, housewives, etc.) }\end{array}$ & -0.214 & 0.807 & -1.051 & 0.349 \\
\hline \multicolumn{5}{|c|}{ The number of the active members of the household (none) } \\
\hline One & 0.580 & 1.787 & -0.249 & 0.779 \\
\hline Two & $0.909^{* *}$ & 2.484 & 0.181 & 1.198 \\
\hline Three & $1.134^{* *}$ & 3.107 & 0.338 & 1.401 \\
\hline Four and more & $1.159^{* *}$ & 3.186 & 0.409 & 1.505 \\
\hline
\end{tabular}

In the first equation, the households of single parents with children prefer to have a single credit 1.93 times more often than single persons. In the second equation, the chances of households of single parents to have two or more credits are 2 times higher than that of single persons.

A similar conclusion can be drawn for households consisting of two spouses without children. For them, the relative risk to take one credit is 1.36 times higher than not to take the credit. Households consisting of spouses with children have the highest chances to take one credit: 2.38 times higher. In households consisting of married couples with children and other relatives, the chances to have a single credit against having no credits are 2.08 times higher than in households of single persons.

For comparison of the chances of having two or more credits in relation to the absence thereof, the chances of 
spouses without children are 1.75 times higher than the chances of singles, of spouses with children are 3.97 times higher, of spouses with children and other relatives are 2.28 times higher, and in complex households without children, the chances are 3.2 times higher.

An increase in the number of employed members in a household increases the chances to take out one credit, but this dependence weakens for two or more credits.

In the first equation, for the households that are in the second income quintile, compared to households in the first quintile, the chances of those who had no credits to take out one credit are 1.38 times higher. Accordingly, the chances of households in the third, fourth, and fifth quintiles are 1.21; 1.24; and 1.39 times higher.

The chances of predominance in the third and fifth quintiles are statistically significant. That is, relatively more profitable households are more active in the credit behavior.

In the second equation, the chances of having two or more credits are higher in all quintiles as compared to the first one.

Education significantly affects the chances of having one credit against having no credits. Since it is not possible to determine the aggregate level of education of a household, we have taken as an estimate the level of education of respondents, which, of course, contains an error, since a respondent can be a household member who does not determine its credit intentions and behavior. Nevertheless, the obtained results have reasonable interpretation, and we believe that they can be trusted. For example, with regard to the households, in which the respondent's education is below secondary, the chances of households, in which the respondent has general secondary education, to have a credit are 1.88 times higher than not to have one. The chances of households, in which the respondent has elementary vocational education are 2.08 times higher, vocational education -2.45 times higher, and higher education -1.73 times higher.

The second equation has a similar picture, but the chances of having two or more credits uniformly increase along with the increasing level of education, but, nevertheless, the most intensive in this field those households are, which have higher and postgraduate education.

Geographic location of households significantly affects the borrowing activity. For example, in the first equation, for the households living in areas that are not "outsiders" according to the accepted typology, the chances to have one credit are statistically significantly higher than to have no credits, compared to the "outsiders." In the second equation, there is an opposite picture: the probability of having two or more credits is significantly higher in the outsider regions.

Compared with regional centers, the chances of having one credit in cities are higher than of having no credits, but this relationship is not statistically significant. In urban-type settlements and villages, the chances of having one credit are lower than the chances of having no credits.

We also checked whether the effect of the predictor variables in the prediction of "no credits" against "one credit" and "two or more credits" is equivalent to the effect of the same variables in the prediction of "two or more credits" versus "no credits."

Testing has shown that the effects are statistically significantly different for the variables "spouses with children", "urban-type settlement" for all types of regions, the third quintile, and households or retirees.

Thus, working spouses with children living in all types of settlements, except urban-type settlements, whose incomes are concentrated in the lower and upper quintiles are the most active borrowers. The spread across quintiles can be explained by the fact that some of the more affluent households focus on expensive credits such as car loans, mortgages, and the less affluent households focus on purchasing home appliances on credit.

\subsection{The model of credit types}

In modeling the credit behavior, in addition to the number of credits, it is necessary to consider the type of credit because it is much easier to pay for, for example, household appliances than for real estate.

Assessment of logistic binary choice models, in which the dependent variables were the types of credits, is provided in Table 3. The variable took the value equal to 1 if the credit of this type had taken place; otherwise, the value was 0. 
Table 3. The logistic model of credit types

\begin{tabular}{|c|c|c|c|c|c|}
\hline & Home appliances & Furniture & Car & Real estate & Repair \\
\hline Free term & -0.15 & -2.83 & -5.58 & - & - \\
\hline \multicolumn{6}{|c|}{ Demographic type of household (single) } \\
\hline Single-parent families & $0.48^{* k}$ & 0.37 & -0.05 & $2.54^{* *}$ & $2.02^{* *}$ \\
\hline Spouses without children & 0.09 & 0.03 & $0.77^{\star *}$ & 1.59 & $1.63^{* *}$ \\
\hline Spouses with children & $0.47^{* *}$ & $0.57^{* *}$ & $1.44^{\star \star \star *}$ & $4.60^{\star * *}$ & $2.19^{* *}$ \\
\hline Complex with no children & $0.43^{* t}$ & $0.52^{* *}$ & $1.03^{* k *}$ & $3.93^{* * k}$ & $2.17^{* *}$ \\
\hline Complex with children & $0.35^{\text {*t }}$ & 0.36 & $0.68^{* *}$ & 1.16 & $1.84^{* *}$ \\
\hline \multicolumn{6}{|c|}{20 percent income groups (first) } \\
\hline Second & 0.09 & 0.08 & 0.16 & $1.91^{* *}$ & $1.45^{* *}$ \\
\hline Third & 0.06 & $0.37^{* *}$ & $0.42^{* *}$ & $1.83^{* *}$ & $1.48^{* *}$ \\
\hline Fourth & -0.13 & 0.26 & $0.87^{\star \star \star}$ & $1.74^{* *}$ & $1.88^{* * *}$ \\
\hline Fifth & $-0.31^{\star \star *}$ & 0.07 & $0.89^{* * *}$ & $2.73^{* *}$ & $2.02^{* * *}$ \\
\hline \multicolumn{6}{|c|}{ Region type (outsiders) } \\
\hline Middle & $-0.74^{\star \star *}$ & $-1.15^{* * *}$ & $2.31^{* * *}$ & 2.03 & $0.32^{* \star *}$ \\
\hline Relatively developed or ahead by income & $-0.86^{* k \star}$ & $-0.75^{\star \star *}$ & $2.43^{* * *}$ & 2.36 & $0.32^{* k *}$ \\
\hline Leaders & $-1.07^{\star \star \star}$ & $-1.48^{* * *}$ & 2.29 & 1.36 & $0.21^{* * *}$ \\
\hline \multicolumn{6}{|c|}{ Type of settlement (Regional center) } \\
\hline City & -0.01 & $0.09^{* k *}$ & 0.12 & 1.04 & $1.45^{* *}$ \\
\hline Urban-type settlement & $-0.92^{\star \star \star}$ & -0.87 & 0.18 & 0.29 & $0.43^{* *}$ \\
\hline Rural-type settlement & $-0.34^{\star \star *}$ & $0.18^{k * k}$ & $0.31^{* \star *}$ & 0.72 & $1.51^{* *}$ \\
\hline \multicolumn{6}{|c|}{ Education of the responder (up to 9 years of study) } \\
\hline 9-11 years of study & $0.61^{* k *}$ & $0.51^{*}$ & 0.27 & 1.90 & 1.18 \\
\hline Elementary vocational education & $0.56^{* *}$ & $0.55^{*}$ & 0.18 & 2.09 & 1.43 \\
\hline Secondary vocational education and undergraduate education & $0.44^{* *}$ & $0.49^{*}$ & 0.33 & 2.08 & 1.37 \\
\hline Higher and postgraduate education & $0.43^{* k t}$ & $0.57^{*}$ & $0.59^{*}$ & 4.14 & 1.05 \\
\hline \multicolumn{6}{|c|}{ Employment type of the household (all members of the household are "active", i.e. are self-reliant financially) } \\
\hline $\begin{array}{c}\text { retirees + "inactive" (i.e. financially dependent on the other } \\
\text { members of the household) }\end{array}$ & $-1.82^{*+* k}$ & -0.59 & -2.76 & 1.76 & 0.32 \\
\hline at least one member of the household is active & -0.09 & -0.18 & 0.05 & $0.56^{\star \star * *}$ & 1.07 \\
\hline $\begin{array}{c}\text { all members of the household are "inactive" (this includes the } \\
\text { unemployed, students, the disabled, housewives, etc.) }\end{array}$ & -1.12 & -0.22 & -1.28 & 1.59 & 0.46 \\
\hline \multicolumn{6}{|c|}{ The number of active members in the household (none) } \\
\hline None & - & - & - & - & - \\
\hline One & -0.62 & 0.63 & -0.88 & $13.01^{* *}$ & 0.74 \\
\hline Two & -0.32 & 0.86 & -0.26 & $13.55^{\text {*k }}$ & 0.88 \\
\hline Three & -0.30 & 0.94 & -0.01 & $10.02^{* *}$ & 0.99 \\
\hline Four and more & -0.29 & 0.81 & 0.19 & $7.72^{* *}$ & 0.89 \\
\hline
\end{tabular}

Compared with those who have never taken credits for home appliances, the probability of buying them on credit is statistically higher for all types of households rather than the singles. Households with children have the highest chances: 1.6 times higher than households of single persons.

The position of a household in the distribution by 20 percent groups of per capita income does not significantly affect the having of credit to the fifth quintile, where the chances of having such a credit are lower, 0.73 of the first quintile, which can be explained by the fact that the most affluent households buy appliances for cash.

With the increasing level of education, the chances to take a credit increase, compared with the group of households where the respondent has education below secondary, but prevail in the group of people with secondary education. So the chances of those who have general secondary and specialized secondary education are 1.6 times higher.

Households purchasing home appliances, video equipment, computers, and the like are the most active borrowers, and most often, these are middle-class families living in cities and not rich regions, in which the majority of members of a family work, children grow, and there are other family members who help repay credits.

With regard to loans for the purchase of furniture, the chances of this type of credit are 1.7 times higher in families with children with medium income. Families with children more often took furniture loans.

The highest probability of purchasing a car on credit is in households with children, and especially where there are other relatives in addition to parents. For example, in families with children the chances of taking a car loan are 4 times higher than those of singles. 
The likelihood of taking a car loan increases along with the household income growth. In the fifth quintile, this likelihood is 2.45 times higher than in the first one.

Education does not affect the decision on the car loan. The number of people employed in a household does not have any statistically significant impact on the likelihood to take a car loan, but the risk to buy a car on credit is significantly lower in families, in which there are no self-employed members compared with the outsider regions. Households living in more economically developed regions are much more likely to take out car loans.

Compared with residents of regional centers, car loans are more often taken by villagers.

Real estate loans are taken out 4 times more often by families with children, as well as complex structure households, which makes sense, since a larger household size means stronger need to expand the dwelling or divide it.

When applying for a real property loan, the significant variables are the number of employed members of a household.

Households of singles more rarely take out loans for housing repair. Single parents with children, spouses with children, and complex households without children do it 2.02, 2.19, and 2.16 times more often, respectively.

\subsection{The model of the relationship between having a credit and having arrears}

The growth of overdue loans actualizes the task of identifying the relationship between having a credit and having arrears. This is possible when using bivariate probit models (Table 4).

With two binary variables, we can observe four possible outcomes. In the GGS data, it is the variable "having a credit", which takes the value of 1 , if there is a credit, and is equal to 0 if there is no credit, and the variable "having arrears," takes the value of 1 in the case of arrears and zero in the case of no arrears.

The questions about payment delays were formulated as follows: "During the past 12 months, has it happened so that your household was unable to make the next payment, such as: rental payment; payment for a real property loan; payment for utilities, electricity, water, gas, etc.; payment of an installment when buying anything on an installment plan or on credit."

Table 4. The bivariate probit model of the the risk of arrears of obligatory payments

\begin{tabular}{|c|c|c|c|}
\hline Variables & Have or had a loan & Have arrears & Marginal effect \\
\hline \multicolumn{4}{|c|}{ Demographic type of the household (single) } \\
\hline Single-parent families & $0.40^{* \star *}$ & 0.11 & -0.01 \\
\hline Spouses without children & $0.21^{\text {*k* }}$ & $-0.22^{* *}$ & $0.02^{*}$ \\
\hline Spouses with children & $0.62^{* k *}$ & -0.02 & $0.03^{* *}$ \\
\hline Complex without children & $0.51^{* * *}$ & 0.07 & $0.02^{* *}$ \\
\hline Complex with children & $0.33^{k * k}$ & 0.05 & 0.02 \\
\hline \multicolumn{4}{|c|}{20 percent income groups (first) } \\
\hline Second & $0.18^{* \star \star}$ & $-0.29^{* k *}$ & $-0.01^{* *}$ \\
\hline Third & $0.17^{* *}$ & $-0.38^{* * *}$ & $-0.02^{* k *}$ \\
\hline Fourth & $0.18^{\text {t* }}$ & $-0.55^{\text {k* }}$ & $-0.03^{k * k}$ \\
\hline Fifth & $0.20^{* *}$ & $-0.78^{\text {*** }}$ & $-0.04^{\star k *}$ \\
\hline \multicolumn{4}{|c|}{ Region type (outsiders) } \\
\hline Medium & -0.03 & $-0.56^{\text {*** }}$ & $-0.05^{\text {*** }}$ \\
\hline Relatively developed or ahead by income & $-0.04^{*}$ & $-0.45^{* \star *}$ & $-0.03^{* k *}$ \\
\hline Leaders & $-0.30^{* *}$ & $-0.43^{* *}$ & $-0.03^{* k *}$ \\
\hline \multicolumn{4}{|c|}{ Type of settlement (regional center) } \\
\hline City & 0.08 & $-0.24^{* \star *}$ & -0.01 \\
\hline Urban-type settlement & $-0.33^{\text {*k* }}$ & $-0.44^{* \star *}$ & -0.03 \\
\hline Rural-type settlement & -0.03 & $-0.37^{\star * *}$ & -0.03 \\
\hline \multicolumn{4}{|c|}{ Education of the responder (up to 9 years of study) } \\
\hline 9-11 years of study & $0.39^{* * *}$ & $0.34^{\star \star \star}$ & $0.05^{\star \star *}$ \\
\hline Elementary vocational education & $0.44^{* * *}$ & $0.35^{\text {** }}$ & $0.06^{* * *}$ \\
\hline Secondary vocational education and undergraduate education & $0.33^{k * k}$ & 0.16 & $0.03^{* *}$ \\
\hline Higher and postgraduate education & $0.33^{\text {k*k }}$ & 0.06 & $0.02^{*}$ \\
\hline \multicolumn{4}{|c|}{ The number of active members in the household (none) } \\
\hline One & $0.21^{*}$ & -0.41 & -0.02 \\
\hline Two & $0.45^{*}$ & -0.41 & -0.02 \\
\hline Three & $0.57^{\text {t* }}$ & -0.53 & -0.02 \\
\hline More than three & $0.60^{\text {** }}$ & $-0.62^{*}$ & -0.03 \\
\hline
\end{tabular}




\begin{tabular}{|c|c|c|c|}
\hline \multicolumn{3}{|c|}{ Employment type of the household (all members of the household are "active", i.e. are self-reliant financially) } \\
\hline $\begin{array}{c}\text { retirees + "inactive" (i.e. financially dependent on the other members } \\
\text { of the household) }\end{array}$ & $-0.56^{* *}$ & $-0.71^{* *}$ & $-0.06^{* * *}$ \\
\hline $\begin{array}{c}\text { at least one member of the household is active } \\
\text { all members of the household are "inactive" (this includes the } \\
\text { unemployed, students, the disabled, housewives, etc.) }\end{array}$ & $-0.19^{* *}$ & $-0.16^{* *}$ & $-0.02^{* *}$ \\
\hline
\end{tabular}

${ }_{\star \star * *},{ }^{*},{ }^{*}$ is significant at the level of 1,5 , and $10 \%$, respectively. The reference categories are shown in parentheses.

The first model implies that the probability of having a credit is statistically significantly higher for all types of households, except for singles; and it increases with the number of workers in the household and per capita income. Credits are preferable for people with elementary and secondary vocational education, living in cities of regions that are not outsiders. This result is consistent with that obtained in the multinomial model of the intensity of credit behavior.

The second model suggests that, compared with all other types of households, households of parents with children are less likely to become debtors. The more employed persons household has and the higher the income is, the lower the risk of arrears is. The highest risk of arrears is among those who have general secondary, elementary and secondary vocational education, that is the most active credit consumers. The lowest risk of arrears is among households living outside the outsider regions and not in regional centers.

The total marginal effect after applying the bivariate probit model is 0.046 , that is, the having of a credit increases the probability of having arrears by $5 \%$ on the average.

Let us discuss the marginal effects of statistically significant variables. The risk of arrears in case of having a credit is higher by $2-3 \%$ in complex households. The highest risk of arrears is present among households, in which respondents indicated that they had general secondary or elementary professional education: the increase is $5 \%$ and $6 \%$, respectively. The higher the household income is, the lower the risk of arrears is: in the second 20 percent group, the risk is lower by $1 \%$; in the third - by $2 \%$; in the fourth - by $3 \%$; and in the fifth - by $4 \%$.

The increase in the number of employees reduces the risk of arrears, but not statistically significantly, and the type of employment of the household - very significantly. for example, compared with households where all its members are financially self-reliant, in the households where there are retirees + "inactive" (i.e. financially dependent on the other members of the household) having a credit, the debt risk is lower by $6 \%$, and for those where at least one member of the household is "active" - by $2 \%$. This result can be explained by the fact that these households being financially weaker do not take out expensive loans and treat them more responsibly.

\subsection{The model of relationship of credit intentions and credit experience}

Using the bivariate probit model (Table 5), we can estimate the relationship of credit intentions and credit experience. There are four possible strategies: 1) the household has had a credit, but is about to purchase another amenity on credit again; 2) the household has not taken out credits before, but is going to; 3 ) the household has had a credit and does not intend to take out credits in the future; 4) the household has not taken out credits and does not intend to borrow.

Table 5. Bivariate probit model of credit intentions

\begin{tabular}{|c|c|c|c|}
\hline & Most likely to take out a credit & Had a credit & Marginal effect \\
\hline Free term & -0.20 & -1.30 & \\
\hline \multicolumn{4}{|c|}{ Demographic type of household (single) } \\
\hline Single-parent families & $0.39^{\text {*t }}$ & $0.46^{* \star \star}$ & $0.16^{\star \star \star}$ \\
\hline Spouses without children & $0.16^{\star k *}$ & $0.24^{* * *}$ & $0.07^{\star \star k}$ \\
\hline Spouses with children & $0.62^{\star \star \star}$ & $0.65^{\star \star \star}$ & $0.24^{\star \star \star}$ \\
\hline Complex without children & $0.48^{* * *}$ & $0.55^{\star \star \star}$ & $0.19^{* \star *}$ \\
\hline Complex with children & $0.33^{\star * \star}$ & $0.36^{* \star *}$ & $0.12^{\star \star \star}$ \\
\hline \multicolumn{4}{|c|}{20 percent income groups (first) } \\
\hline Second & 0.02 & $0.18^{\star \star \star}$ & $0.03^{* *}$ \\
\hline Third & 0.01 & $0.16^{* *}$ & $0.03^{*}$ \\
\hline Fourth & -0.01 & $0.15^{* *}$ & 0.02 \\
\hline Fifth & $-0.14^{\star *}$ & $0.22^{\star \star \star}$ & 0.01 \\
\hline \multicolumn{4}{|c|}{ Region type (outsiders) } \\
\hline Middle & $-0.77^{\star \star \star}$ & 0.11 & $-0.10^{* \star *}$ \\
\hline Relatively developed or ahead by income & $-0.94^{* * *}$ & 0.07 & $-0.14^{\star k \star}$ \\
\hline Leaders & $-1.17^{\star \star \star}$ & -0.16 & $-0.17^{\star \star \star}$ \\
\hline
\end{tabular}




\begin{tabular}{|c|c|c|c|}
\hline & Most likely to take out a credit & Had a credit & Marginal effect \\
\hline \multicolumn{4}{|c|}{ Type of settlement (regional center) } \\
\hline City & -0.01 & 0.07 & 0.01 \\
\hline Urban-type settlement & $-0.09^{* * *}$ & $-0.26^{\text {**k }}$ & $-0.05^{* *}$ \\
\hline Rural-type settlement & 0.18 & 0.02 & $0.03^{* *}$ \\
\hline \multicolumn{4}{|c|}{ Education of the responder (up to 9 years of study) } \\
\hline 9-11 years of study & $0.27^{\star \star * *}$ & $0.41^{* * *}$ & $0.12^{* k *}$ \\
\hline Elementary vocational education & $0.37^{\star k \star}$ & $0.47^{\star * \star}$ & $0.15^{* k *}$ \\
\hline $\begin{array}{l}\text { Secondary vocational education and undergraduate } \\
\text { education }\end{array}$ & $0.28^{* * *}$ & $0.36^{* * *}$ & $0.11^{* * *}$ \\
\hline Higher and postgraduate education & $0.37^{\star \star \star *}$ & $0.35^{* * *}$ & $0.13^{* \star \star}$ \\
\hline \multicolumn{4}{|c|}{ The number of active members in the household (none) } \\
\hline None & - & - & \\
\hline One & 0.27 & $0.25^{* *}$ & 0.09 \\
\hline Two & 0.36 & $0.50^{* *}$ & $0.15^{* *}$ \\
\hline Three & $0.53^{* *}$ & $0.61^{* *}$ & $0.22^{* *}$ \\
\hline More than three & $0.51^{* *}$ & $0.61^{* *}$ & $0.21^{* *}$ \\
\hline \multicolumn{4}{|c|}{ Employment type of the household (all members of the household are "active", i.e. are self-reliant financially) } \\
\hline $\begin{array}{c}\text { retirees + "inactive" (i.e. financially dependent on the other } \\
\text { members of the household) }\end{array}$ & -0.34 & $-0.52^{* *}$ & $-0.13^{* *}$ \\
\hline at least one member of the household is active & -0.08 & $-0.08^{*}$ & $-0.03^{* *}$ \\
\hline $\begin{array}{l}\text { all members of the household are "inactive" (this includes the } \\
\text { unemployed, students, the disabled, housewives, etc.) }\end{array}$ & -0.30 & -0.17 & -0.07 \\
\hline
\end{tabular}

${ }^{* * *},{ }^{* *},{ }^{*}$ is significant at the level of 1,5 , and $10 \%$, respectively. The reference categories are shown in parentheses.

Lonely respondents and families with single parents raising a child are least set to take out a loan again. The chances for spouses with children are by $24 \%$ higher than for singles; the chances of households where children are grown-up are by $19 \%$ higher, and the chances of complex households with children are by $12 \%$ higher.

Compared with households where the respondent was a person with incomplete secondary education, all other educational groups have higher chances, but they are the highest among those who are more educated. Households where the respondent has elementary vocational education have chances to take out a loan again by $15 \%$ higher, and those who have higher education - by $13 \%$ higher.

The more employed members a household has, the higher the likelihood of taking out a loan again is. The chances of households where the number of active members is more than 3 are higher by $21 \%$. Accordingly, the risk for households, in which not all of its members are self-reliant, to apply for a loan is significantly lower compared to households where everyone works.

With rising incomes, the chances to apply for a loan increase, but the marginal effects are small and statistically significant only in the first quintile.

For households that has not taken out loans, but are going to, significant marginal effects are observed only in regions. Here, the probability of applying for loans is higher in the "outsider" regions. The probability of applying for loans of low-income households in this group is higher. significant.

For households that have taken out loans, but do not intend to do it again, the regional effects are the most

Thus, the most clearly defined groups in the credit behavior are households that do not consistently show positive intentions regarding this segment of the financial services market. These are mostly people living alone with relatively low income who often do not have income from employment and retirees with either high level of education or with elementary education living in regions not classified as "outsiders."

The second stable group is households that have become proficient in the credit services market. These are mostly households with children and of complex structure living in large cities, in which there are several employed members. The most active borrowers live in the "outsider" regions.

The choice of the type of a loan in these households is mainly determined by the income level.

\section{Discussion}

The calculation of the prediction probability by the built models enabled making portraits of the most and least probable savers and borrowers.

Households, for which the probability to have savings is at least 0.7 , belong to the highest income group, usually 
consist of spouses without children, live in two-bedroom apartments in regional centers and in the "medium" regions ${ }^{1}$. In these households, the members with higher or postgraduate education, as well as "inactive" members and retirees are likely to be living.

households, for which the probability to have savings is between 0.5 and 0.7 , belong to the fourth 20 percent income group, usually consist of spouses without children, live in two-bedroom apartments located in regional centers and in "medium" regions. These households have at least one employed member or retirees, and at least one member of the household has higher or postgraduate education.

Households, for which the probability to have savings is less than 0.5 , belong to the first two 20 percent income groups; live in rural settlements; consist of unemployed members; do not have a car and a garden cottage; and have children.

The probability of being included in the first group of households that have not taken out loans from 2000 to 2011 is highest for single people and spouses without children with one employed member, with low level of education, retirees or dependents, and for households that are in the middle of the income distribution and live in urban-type settlements.

The group of households that have had one loan most probably includes households with medium level of education, in which all employable are active, so the level of their income is high enough; they tend to live in large cities and medium regions, or in regions leading by income. This group also includes those with the low level of per capita income and needing loans for current needs.

The category of active borrowers most often includes complex families where several generations of relatives with children live together; they are described by a high level of education, above average income; all employable members are active; and they live primarily in medium-sized cities of outsider regions.

\section{Conclusions}

To summarize, we can note the following:

1. Households' income affects their financial behavior. With rising incomes, the likelihood of having savings and the frequency of requests for loans grow.

2. The most prone to having savings are households belonging to the highest income group consisting of spouses without children, living mainly in two-bedroom apartments located in regional centers and in "medium" regions. These households are likely to include members with higher or postgraduate education, as well as "inactive" members and retirees.

3. The most prone to applying for loans are complex families where several generations of relatives with children live together. They normally have a high level of education, above average income; all employable members of them are active; and they primarily live in medium-sized cities of outsider regions.

Modeling socioeconomic dependences, in particular the financial behavior of households, requires prior and thorough analysis of the essence of the phenomena analyzed, as well as the nature of the variables with account of their mutual influences. The relative ease of access to software offering various modifications of the regression analysis often leads inexperienced analysts to gross errors. The presented approaches to econometric modeling of financial behavior of households allow avoiding such errors.

\section{Acknowledgments}

This publication was financially supported by the Ministry of Education and Science of the Russian Federation within the framework of the base part of the state order №2014/176 (project code 2245). This publication was financially supported by the grant from the Russian Science Foundation № 15-02-00600 "Identifying threats to the growth of systemic risk in the Russian financial market based on the definition of vulnerabilities of financial institutions and households to the risk of money laundering".

\section{References}

Duesenberry, J.S. (1974). Income, Saving and the Theory of Consumer Behaviour. Cambridge, MA: Harvard University Press. Friedman, M. (1957). A theory of the consumption function. Princeton: Princeton University Press. Greene, W.H. (2000). Econometric Analysis. 4th edition. Prentice-Hall International, Inc.

\footnotetext{
${ }^{1}$ According to the classification of N. Zubarevich
} 
Katona, G. (1951). Psychological Analysis of Economic Behaviour. N.Y., McGrow-Hill.

Kuzina, O., Roschina, Y. (1998). Modeling of the Russian households savings behaviour. The final report on the project RPEI \#98-041. Modigliani, F., \& Neisser, H. (1953). National Incomes and International Trade, University of Illinois Press

Burdyak, A.Ya. (2014). Cash savings of households at different stages of the life cycle. Finansovy Zhurnal, Moscow, 1(19), pp. 129-140. Galishnikova, E.V. (2012). Financial behavior of the population: save or spend. State University of the Russian Finance Ministry. Finansovy Zhurnal, 2, pp. 133-140.

Zubarevich, N.V. (2005). Russian regions: what social space do we live in? Independent Institute for Social Policy, Moscow: Pomatur.

Ibragimova, D.H. (2013). The savings behavior of the Russians in the period of 2009-2013. Bankovskoye Delo, Moscow, 12, pp. 48-53.

Ibragimova, D.H. (2009). Types of the saving and credit behavior. Monitoring Obshchestvennogo Mneniya, 2, pp. 156-171.

Keynes, J.M., (1999). The General Theory of Employment, Interest and Money. Moscow: Gelios ARV.

Kuzina, O.E. (2009). The savings strategies of the middle class. In: The Russian middle class: analysis of the structure and financial behavior. Moscow: Ekon-Inform.

Nivorozhkina, L.I. (2014). The impact of consumer lending on the level of inequality and poverty of households. Proceedings of the higher educational institutions, the North Caucasus region, 4, pp. 76-83.

Nivorozhkina, L.I., Ovcharova, L.N., Syniavska, T.G. (2013). Econometric modeling of the risk of defaults on consumer loans. Prikladnaya Ekonometrika, 2, pp. 65-76.

Ovcharova, L.N. (2014). Dynamics of monetary and non-monetary characteristics of the standard of living of Russian households during the years of post-Soviet development: analytical report. Moscow: Fund "Liberal Mission."

Ovcharova, L.N. et al. (2008). Russian households on the eve of the financial crisis: income and financial behavior. Moscow: Independent Institute for Social Policy.

Strebkov, D.O. (2007). Social aspects of the credit behavior of the population. Sotsiologichesky Zhurnal, 1, pp. 83-102.

Strebkov, D.O. (2007). Model of credit behavior and factors determining their choice. Sotsiologicheskye Issledovaniya, 3, pp. 52-62.

Toropova, T.V., Tregubova, A.A., \& Yaraskhanova, E.W. (2013). Savings behavior of Russian households: does the theory conform to the real life? Finansy i Kredit, 41(569), pp. 59-67.

Yarasheva, G. V., \& Burdastova, Y. V. (2013). Saving and credit strategies of households. Narodonaseleniye, 2, pp. 94-102. 